\title{
Geographical Information System and Multi-criteria Based Cellular Automata Markov Model for Urban Growth and Analysis the Case Study of Bungoma Town Kenya
}

\author{
Morris Barasa Waswa, Andrew Thiaine Imwati \\ Department of Geomatic Engineering and Geospatial Information Systems, Jomo Kenyatta University of Agriculture and Technology, \\ Nairobi, Kenya \\ Email address: \\ waswamorris $a$ gmail.com (M. B. Waswa), andrewimwati $a$ gmail.com (A. T. Imwati)

\section{To cite this article:} \\ Morris Barasa Waswa, Andrew Thiaine Imwati. Geographical Information System and Multi-criteria Based Cellular Automata Markov \\ Model for Urban Growth and Analysis the Case Study of Bungoma Town Kenya. American Journal of Environmental Science and \\ Engineering. Vol. 3, No. 1, 2019, pp. 22-30. doi: 10.11648/j.ajese.20190301.14
}

Received: January 9, 2019; Accepted: February 11, 2019; Published: March 11, 2019

\begin{abstract}
Increase in population and the desire to seek new opportunities has contributed to urban growth, putting pressure on facilities in urban centres. Bungoma town, being the headquarter of Bungoma County has undergone radical changes in its physical form, not only in territorial expansion, but also through internal physical transformation. In the process of urbanization, physical characteristic of the town is gradually changing as cropland (agricultural land), vegetation and wetland has been converted to built-up areas. This new urban fabric needs to be analysed to understand the impact of these changes. The aim of this research was to evaluate the suitability of Bungoma town setting, model its growth and predict the future growth of the town based on land cover changes (1985-2015). Landsat satellite images were classified with five land cover classes followed by change detection. To simulate land cover map for Bungoma town in 2030, Markov Chain model and Cellular Automata Markov (CA-Markov) model were used. It was found that built-up area increased over the study period. The major contributors to this change are cropland, vegetation and wetland land cover types. The CA-Markov model results showed that $52 \%$ of the total study area will be converted into built-up area, $19 \%$ to cropland, $20 \%$ to vegetation, $5 \%$ to open spaces and 3\% to wetland by 2030. This would have negative implication on food security in the region which is a major source of income for the inhabitants. There is need therefore for proper land use planning in the area. In addition, vertical urban development should be encouraged to control rapid expansion of the town.
\end{abstract}

Keywords: CA-Markov, Simulate, Suitability

\section{Introduction}

Urbanization is one of the most evident human induced global changes worldwide. In the past 200 years, the world population has increased six times while urban population has multiplied 100 times [1]. Like many other towns in the world, Bungoma town has also face rapid growth without any systematic planning. The town has undergone radical changes in its physical form, not only in territorial expansion but also through internal physical transformation over the last decades [2]. These have created entirely new kinds of urban fabric.

According to Kenya's Concept Paper on National Spatial Plan, Kenya's population is quickly urbanizing and it is estimates that about $50 \%$ of the total population would live in urban areas by the year 2050 [3]. Even though urbanization is fundamental to modernization, economic growth, and development, but at the same time, it has some repercussions on the physical environment [17-18]. Urban areas are already showing signs of strain resulting from high population growth that are not commensurate with infrastructure, service provision, and employment creation. Nearly all Kenyan towns are characterized by serious urban sprawl, poverty, informality, and environmental deterioration, among other negative attributes. In the last 30-40 years, Bungoma has experienced tremendous growth with an average population annual growth rate of $3.2 \%$ which is higher 
compared to Kenya average national growth of $3.4 \%$ [6]. It is evident that land use conversion and management in the urban fringes has been of great concern all over the world. In Kenya, for instance, authorities responsible for land use management and other stakeholders are facing a dilemma as to what would be the most economically viable, technologically feasible, and sustainable land uses in fertile urban rural fringes. According to Musa and Odera, (2015), understanding the changes is critical for planners and resource managers as this will help control and restrict urban growth from eating into the vital but scarce agricultural land. Several approaches have been used to integrate GIS with urban growth modelling [9]. Cellular automata Markov chain, urban land-use modeling has been explored in Idrisi software in a couple of studies [10]. Recently significant effort has been made to integrate urban models in open source modelling platforms such as XULU (eXtendable Unified Land Use) [7, 11]. The current GIS urban modelling techniques are technology driven and further refinement in understanding urban forms is necessary. Different cities have different driving factors of urban land use change. The tools should help in designing effective urban planning policies for sustainable development to be achieved. With the shift of urban modelling from the conventional top-down approach to the current practices in addressing localities, models such as those using diffusion-limited aggregation and cellular automata techniques have demonstrated considerable potential in the mutual benefits of urban modelling and GIS [8].

\section{Materials and Methods}

\subsection{Study Area}

The study was conducted in Bungoma County, Kenya. Bungoma town is located $450 \mathrm{~km}$ from the Kenyan capital Nairobi, on the Great North road to Kampala in Uganda. Its geographical coordinates are latitude $0.5694^{\circ} \mathrm{N}$, longitude $34.5611^{\circ} \mathrm{E}$. The area covers approximately $59.97 \mathrm{~km}^{2}$.

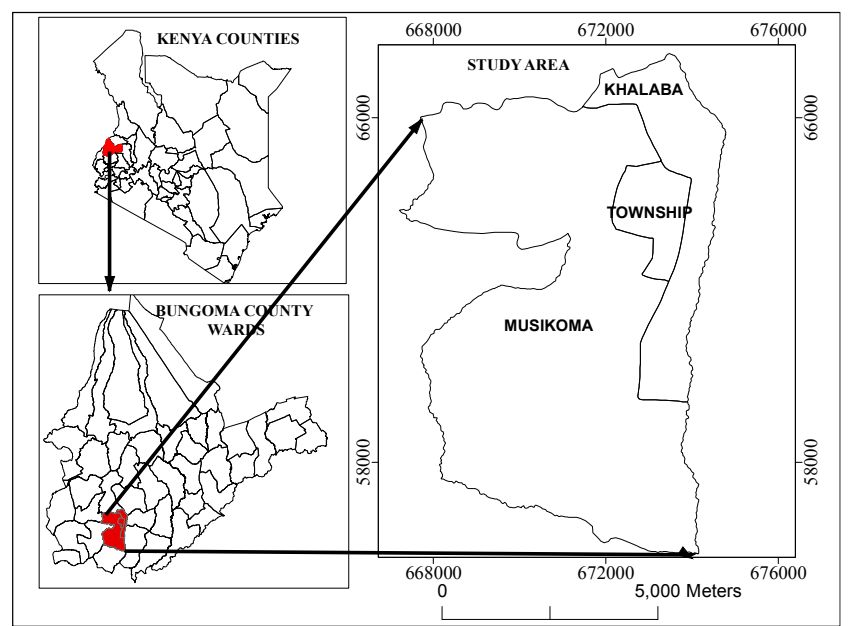

Figure 1. The Study Area covers three wards (Musikoma, Township and Khalaba).

\subsection{Data Collection}

Topographical maps, soils, Geology, Digital Elevation Model (DEM), River Network, Road Network and Landsat satellite images of 1985, 2000 and 2015 downloaded from U.S. Geological Survey website were used in this study.

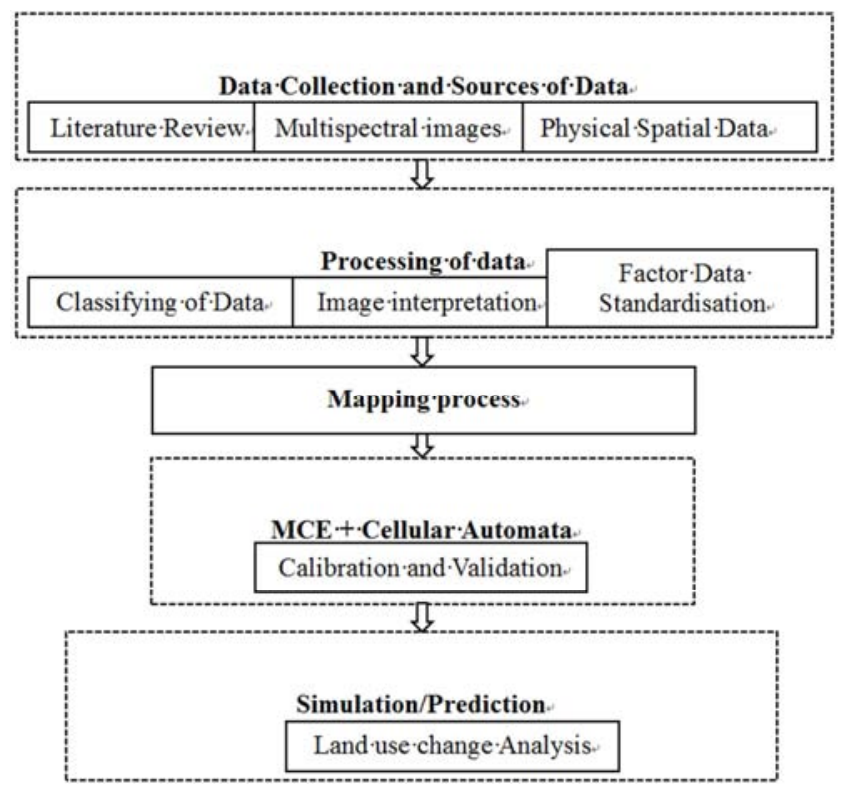

Figure 2. Flow Chart of Methodology.

Landsat satellite images of $30 \mathrm{~m}$ resolution for the years 1985, 2000 and 2015 were collected from the official website of US Geological Survey (USGS) and processed. Preprocessing involved layer staking, image enhancement and sub-setting the area of interest. The clipped images were then classified into five land cover types using ERDAS imagine software. This resulted into various land cover maps. Google earth and GPS points were used to determine classification accuracy. The overall accuracy assessment range of $72 \%$ to $82 \%$ was achieved. In addition, the study used different parameters such as distance from transportation network, soil type, geology and slope to provide a good understanding of the suitable location of the town using Multi-Criteria Decision Model (MCDA) and Geographical Information System (GIS).

Markov Chain and CA-Markov model Modules found in IDRIS Kilimanjaro were utilized to simulate the direction of future growth and development in Bungoma town. Three types of data inputs were required, which include Markov transition areas file, a collection of suitability maps, and classified land-cover maps of 1985, 2000, and 2015 [5], [15].Theland-cover maps were generated through classification of satellite images, while thesuitability maps were generated by aggregation of maps (factors and constraints) through multi-criteria evaluation (MCE) as explained by Bozkaya et al, (2015). Additionally, the transition areas files were prepared through Markov module of the model [4]. 


\section{Results}

In this research, three change detection analyses over time were considered. This included changes between 1985-2000,

\section{0-2015 and 1985-2015.}

The land cover classification statistics summary is given in Table 1. Figure 3 shows spatial changes that were experienced throughout the study period.

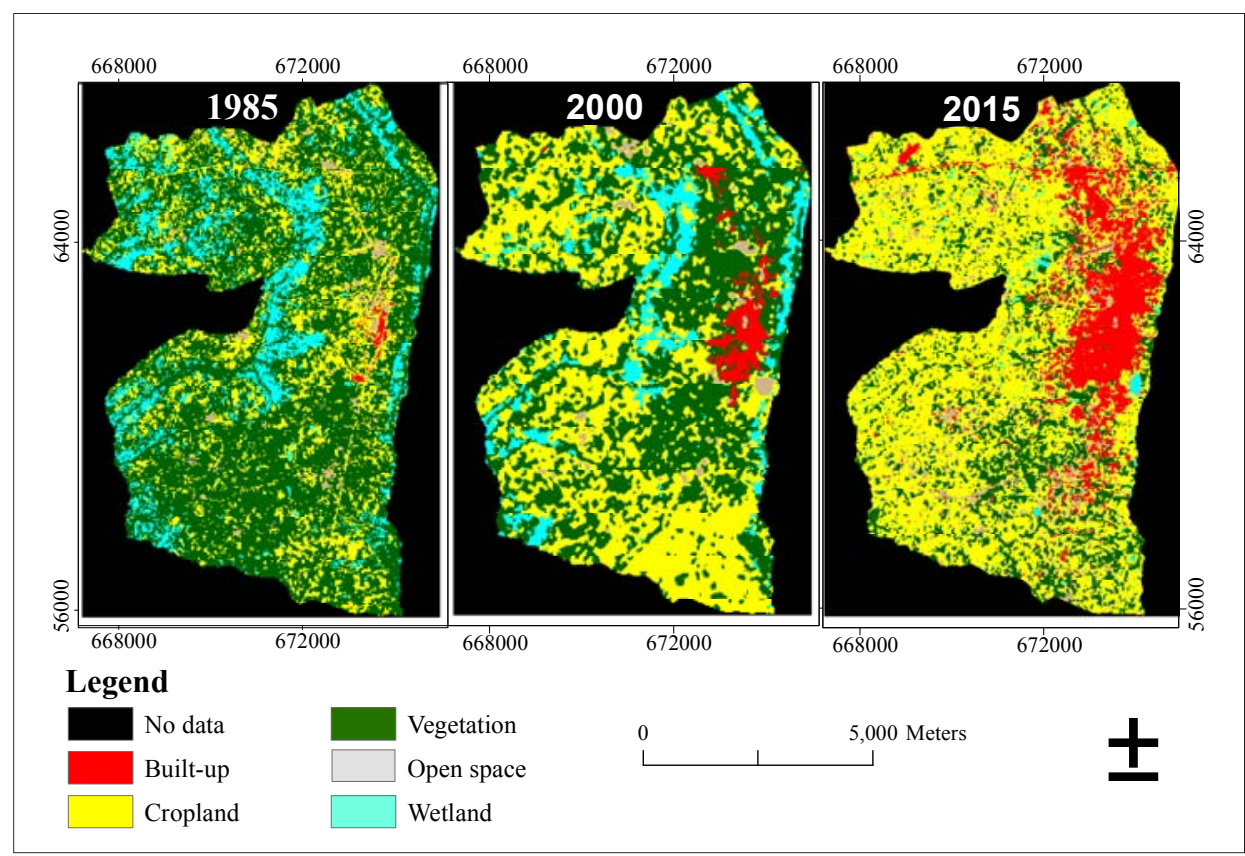

Figure 3. Spatial Land Cover Change of land cover types (1985, 2000, 2015).

Table 1. Land Cover Change Statistics in Hectares (Ha) and Percentages (\%).

\begin{tabular}{|c|c|c|c|c|c|c|c|c|c|c|c|c|}
\hline \multirow[b]{3}{*}{ Land use } & \multicolumn{4}{|l|}{1985} & \multicolumn{4}{|l|}{2000} & \multicolumn{4}{|l|}{2015} \\
\hline & \multirow[b]{2}{*}{$\begin{array}{l}\text { Area } \\
\text { (Ha) }\end{array}$} & \multicolumn{3}{|c|}{$1985-2000$} & \multicolumn{4}{|c|}{$2000-2015$} & \multirow[b]{2}{*}{$\begin{array}{l}\text { Area } \\
(\mathrm{Ha})\end{array}$} & \multirow[b]{2}{*}{$\begin{array}{l}\text { Area } \\
(\%)\end{array}$} & \multicolumn{2}{|c|}{ 1985-2015 } \\
\hline & & $\begin{array}{l}\text { Area } \\
(\%)\end{array}$ & $\begin{array}{l}\text { Change } \\
\text { (Ha) }\end{array}$ & $\begin{array}{l}\text { Change } \\
(\%)\end{array}$ & $\begin{array}{l}\text { Area } \\
\text { (Ha) }\end{array}$ & $\begin{array}{l}\text { Area } \\
(\%)\end{array}$ & $\begin{array}{l}\text { Change } \\
\text { (Ha) }\end{array}$ & $\begin{array}{l}\text { Change } \\
(\%)\end{array}$ & & & $\begin{array}{l}\text { Change } \\
\text { (Ha) }\end{array}$ & $\begin{array}{l}\text { Change } \\
(\%)\end{array}$ \\
\hline Built-up & 24.84 & 0.41 & 159.84 & 2.67 & 184.68 & 3.08 & 665.45 & 11.10 & 850.13 & 14.18 & 825.29 & 13.76 \\
\hline Cropland & 1293.03 & 21.56 & 1259.46 & 21.00 & 2552.49 & 42.56 & 783.27 & 13.06 & 3335.76 & 55.62 & 2042.73 & 34.06 \\
\hline Vegetation & 3784.08 & 63.10 & -1193.13 & -19.90 & 2590.95 & 43.20 & -1360.55 & -22.69 & 1230.40 & 20.52 & -2553.68 & -42.58 \\
\hline Open space & 122.22 & 2.04 & -17.81 & -0.30 & 104.41 & 1.74 & 374.91 & 6.25 & 479.32 & 7.99 & 357.10 & 5.95 \\
\hline Total Area & 5997.00 & & & & 5997.00 & & & & 5997.00 & & & \\
\hline
\end{tabular}

From Table 1, it is clear that over the years 1985 to 2015 cropland areas increased in large percentage from $21.56 \%$ to $55.62 \%$ followed by built-up $0.41 \%$ to $13.76 \%$. It was also noted that vegetation and wetland decreased in high rate from $63.10 \%$ to $20.52 \%$ and from $12.89 \%$ to $1.69 \%$ respectively. Open space land cover type increased by $5.95 \%$. The negative sign implies that the land use is decreasing.

\subsection{Gains and Losses by Category}

From Figure 4, built-up and Cropland (agricultural area) increased over the years within Bungoma township. This means that large new area was transformed into built-up and Cropland (agricultural area) from vegetation land, open space and wetland. The analysis also indicates that vegetation land cover type decreased in large percentage followed by wetland in all the years. Therefore, an abrupt increase in built-up and agricultural area and decrease in vegetation land cover type is quite clear from this analysis.

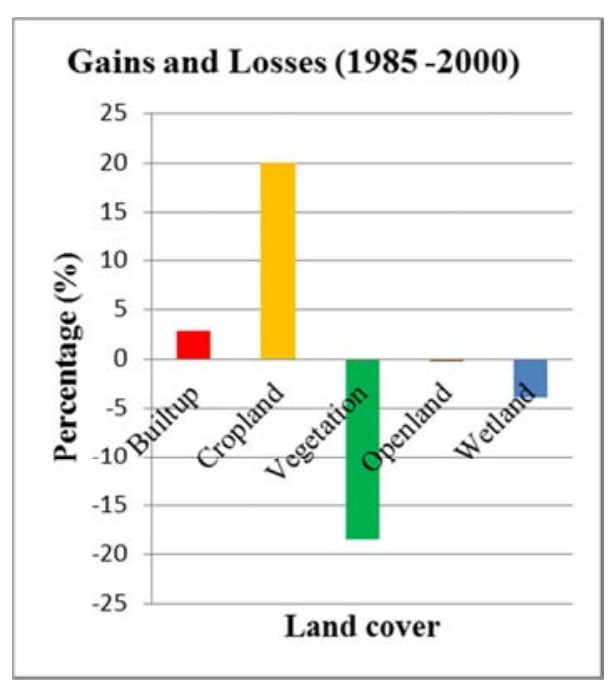



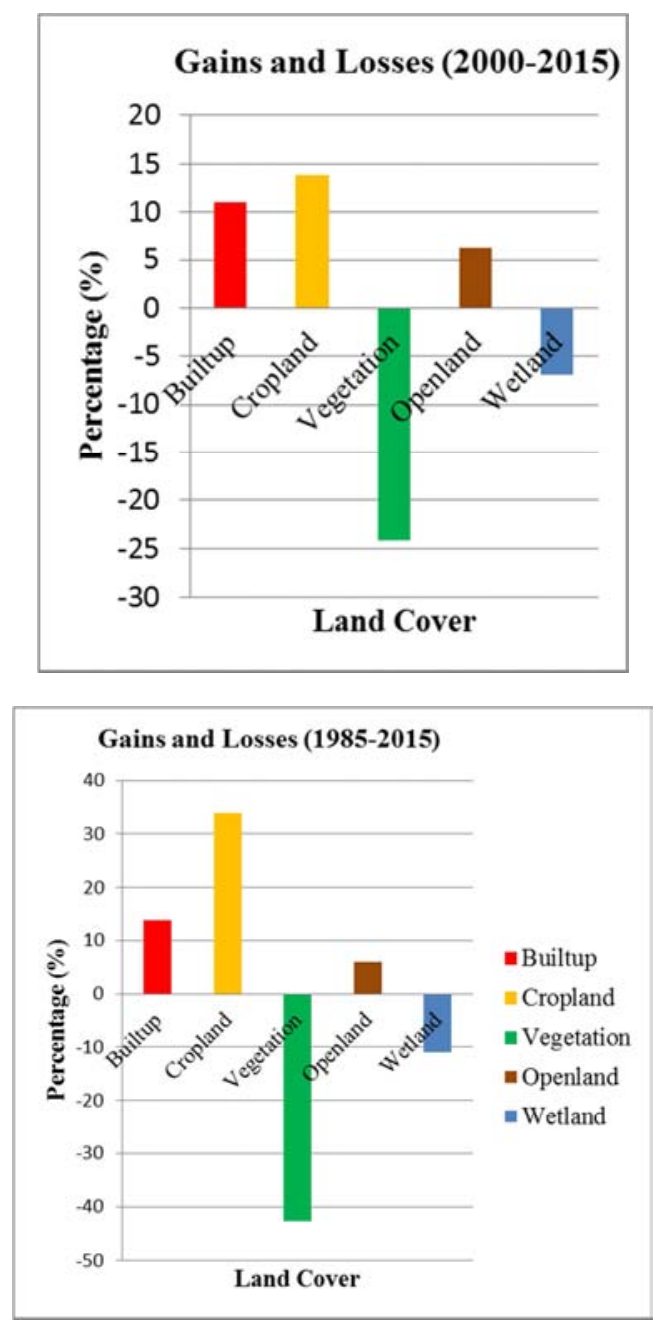

Figure 4. Gains and Losses in Land Cover Types.

\subsection{Contributors to Net Change in Built-up Area}

Figure 5 shows that vegetation land is mostly converted to built-up area followed by cropland, Open space and wetland, throughout the study period. Increase in population has resulted to vegetation clearing

For farming and settlement.

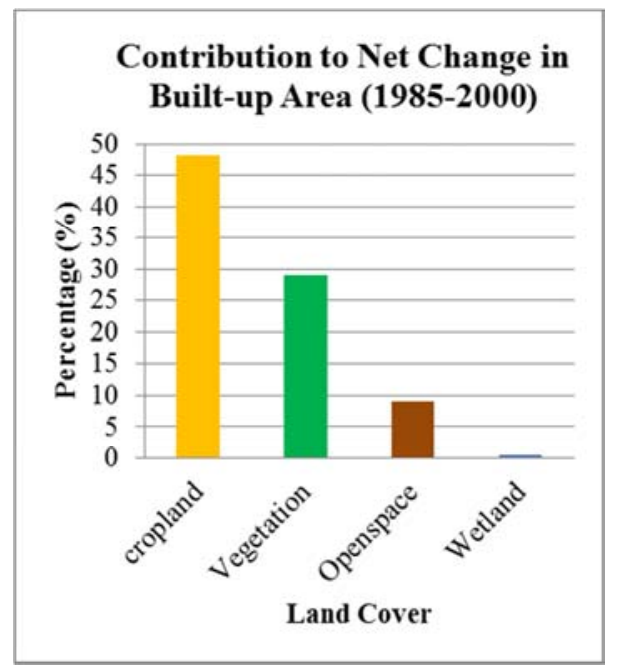

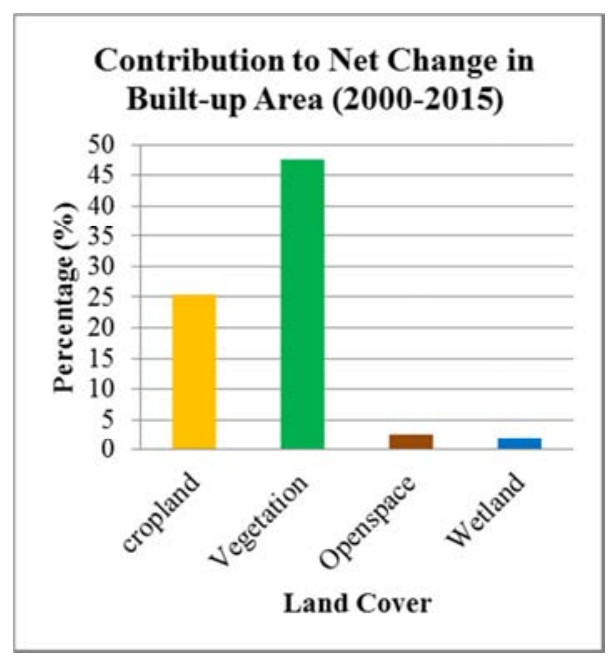

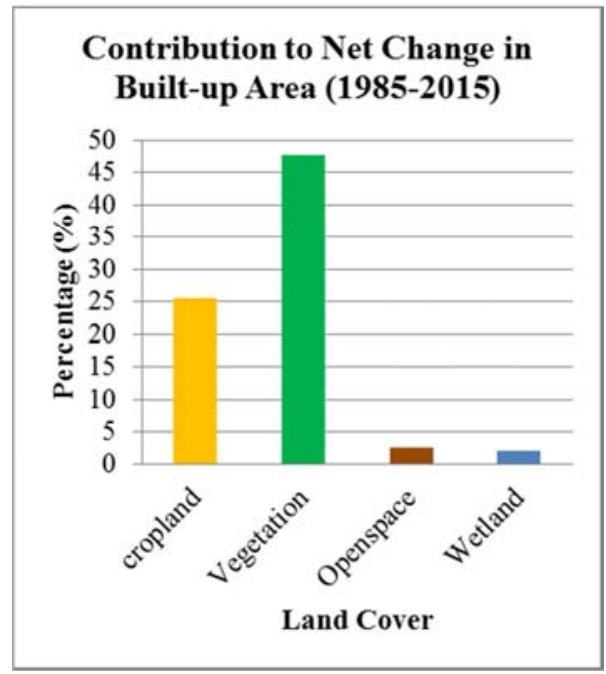

Figure 5. Contributors to Net Change of Built-up Area in Percentage (19852000, 2000-2015, 1985-2015).

\subsection{Transition to Built-Up Area}

From Figure 6, it is clear that agricultural (cropland) area and vegetation land near the town is transiting to built-up area as it expand towards north, east and west. Though cropland around the town is transiting to built-up, it has maintained its increase because it has gained from vegetation land type.

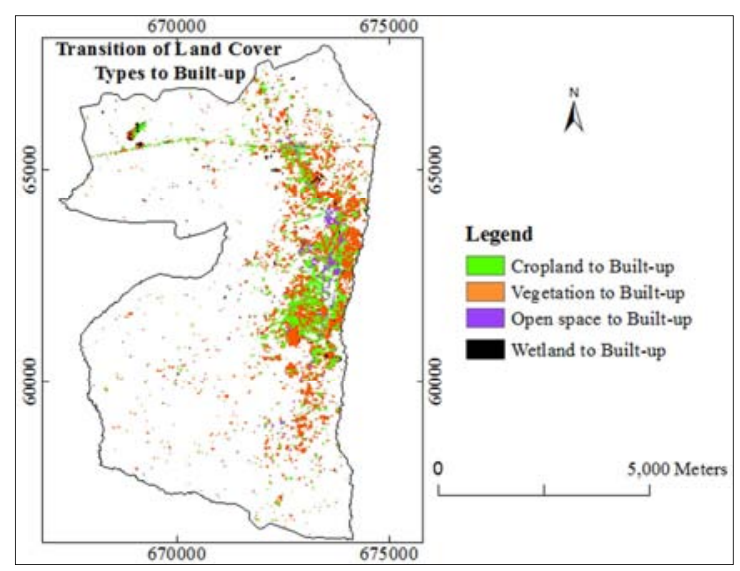

Figure 6. Transition of Land Cover Types to Built-up Area. 


\subsection{Gains and Losses in Land Cover Types}

Based on analysis of Figure 7 and considering the built-up area, the southern part of Bungoma town has experienced a few changes while the north, east and west parts have converted to built-up areas. In these region most of agricultural land and wetland has been converted to built-up areas. It is also noted that there is a massive decrease of wetland along the rivers.

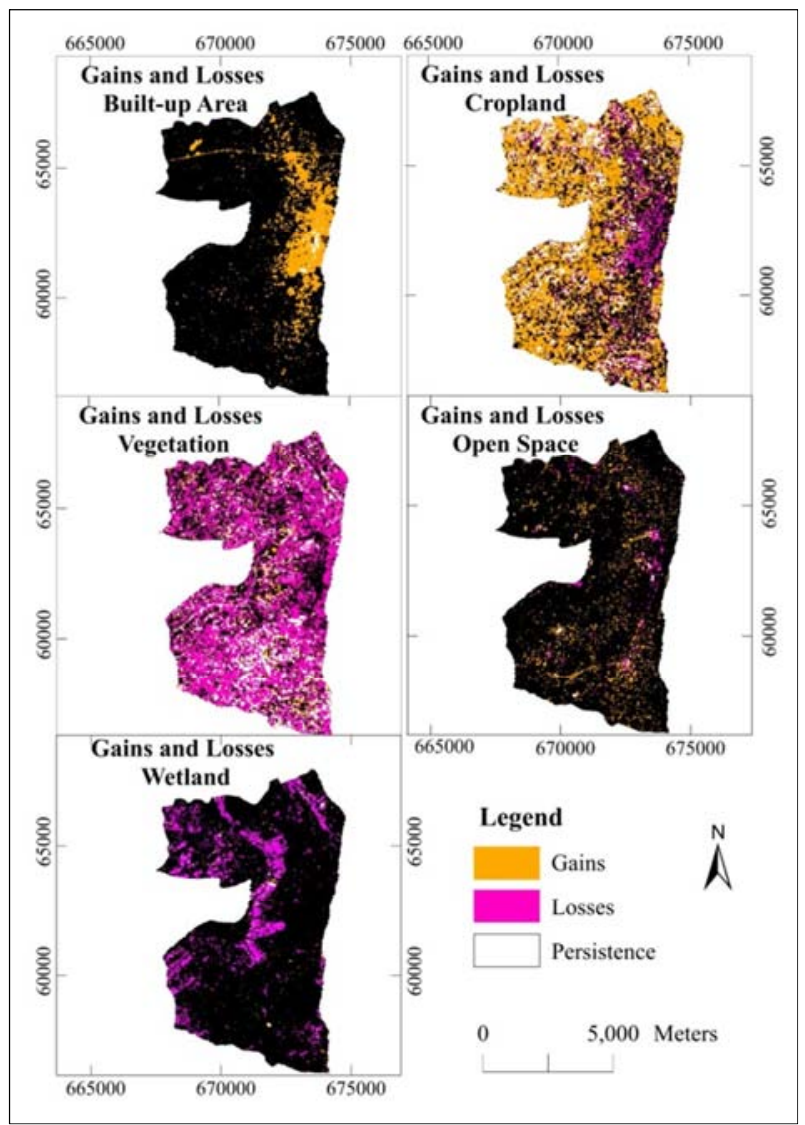

Figure 6. Gains and Losses in Each Land Cover Types (1985-2015).

\subsection{Analysis of Land Suitability for Urban Development}

From suitability analysis, only approximately $4 \%$ of the study area is suitable for urban development. The areas that is moderately suitable for urban development is $71 \%$ and unsuitable area is approximately $25 \%$. The unsuitable areas for urban development includes areas of Musikoma hills, and wet land along rivers Sio and Khalaba. In this area, urban development should be discouraged. Kanduyi junction and town centre present areas suitable for urban development hence urban densification should be encouraged. Moderately suitable areas cover agricultural land and vegetation land cover (see Figure 8).

\subsection{Model Validation and Future Land Use Change Prediction Analysis}

Markov Chain and CA-Markov model Modules found in IDRIS Kilimanjaro were used to predict and simulate the direction of future growth and development in Bungoma town. These models were based on using and evaluating land use/land cover maps of previous years and further predict the spatial distribution of future land uses/land cover. The simulated land use changes were developed in IDRISI to monitor the patterns of spatial urban land use. In this study, land use/land cover maps of 1985 and 2000 were selected as input into the Markov chain model to produce a transition matrix Table 2 and conditional probability images for five land categories by analyzing two qualitative land cover images from two different dates.

From the Transition matrix and aggregated suitability maps created from conditional probability images, future land use/land cover of 2015 was predicted using a base map of 2000 in a span of 15 years (Figure 9). The predicted land cover map of 2015 was validated with the classified land cover map of the same year as shown in Figure10.

Table 2. Markov Probability of Changing among Land Cover Types (1985 - 2000).

\begin{tabular}{llllll}
\hline & Built-up & Cropland & Vegetation & Open Space & Wetland \\
\hline Built-up & 0.6198 & 0.0472 & 0.2624 & 0.0663 & 0.0027 \\
Cropland & 0.0499 & 0.3124 & 0.4093 & 0.0696 & 0.1586 \\
Vegetation & 0.1162 & 0.3073 & 0.3871 & 0.1042 & 0.0848 \\
Open Space & 0.1147 & 0.2544 & 0.2387 & 0.1794 & 0.2128 \\
Wetland & 0.0486 & 0.3206 & 0.2508 & 0.0857 & 0.2914 \\
\hline
\end{tabular}

Table 3. Cells Expected to Transition to Different Classes (1985 - 2000).

\begin{tabular}{llllll}
\hline & Built-up & Cropland & Vegetation & Open Space & Wetland \\
\hline Built-up & 3968 & 302 & 1680 & 1680 & 17 \\
Cropland & 973 & 6089 & 11068 & 7978 & 3092 \\
Vegetation & 2432 & 6434 & 11360 & 8102 & 1776 \\
Open Space & 777 & 1723 & 347 & 1616 & 1441 \\
Wetland & 630 & 4155 & 1546 & 3251 & 3776 \\
\hline
\end{tabular}




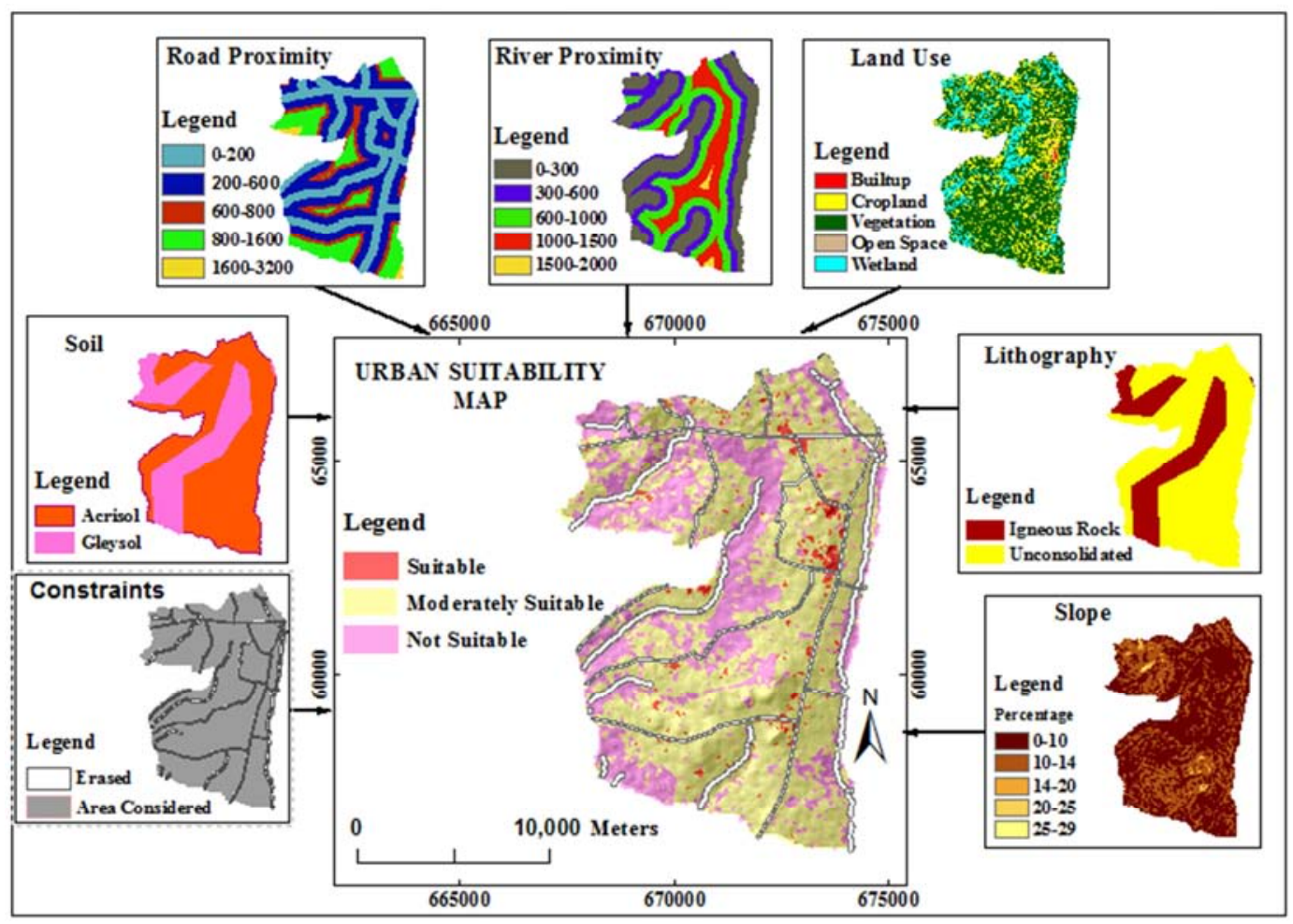

Figure 7. Land Suitability map for Bungoma Town Urban Development.

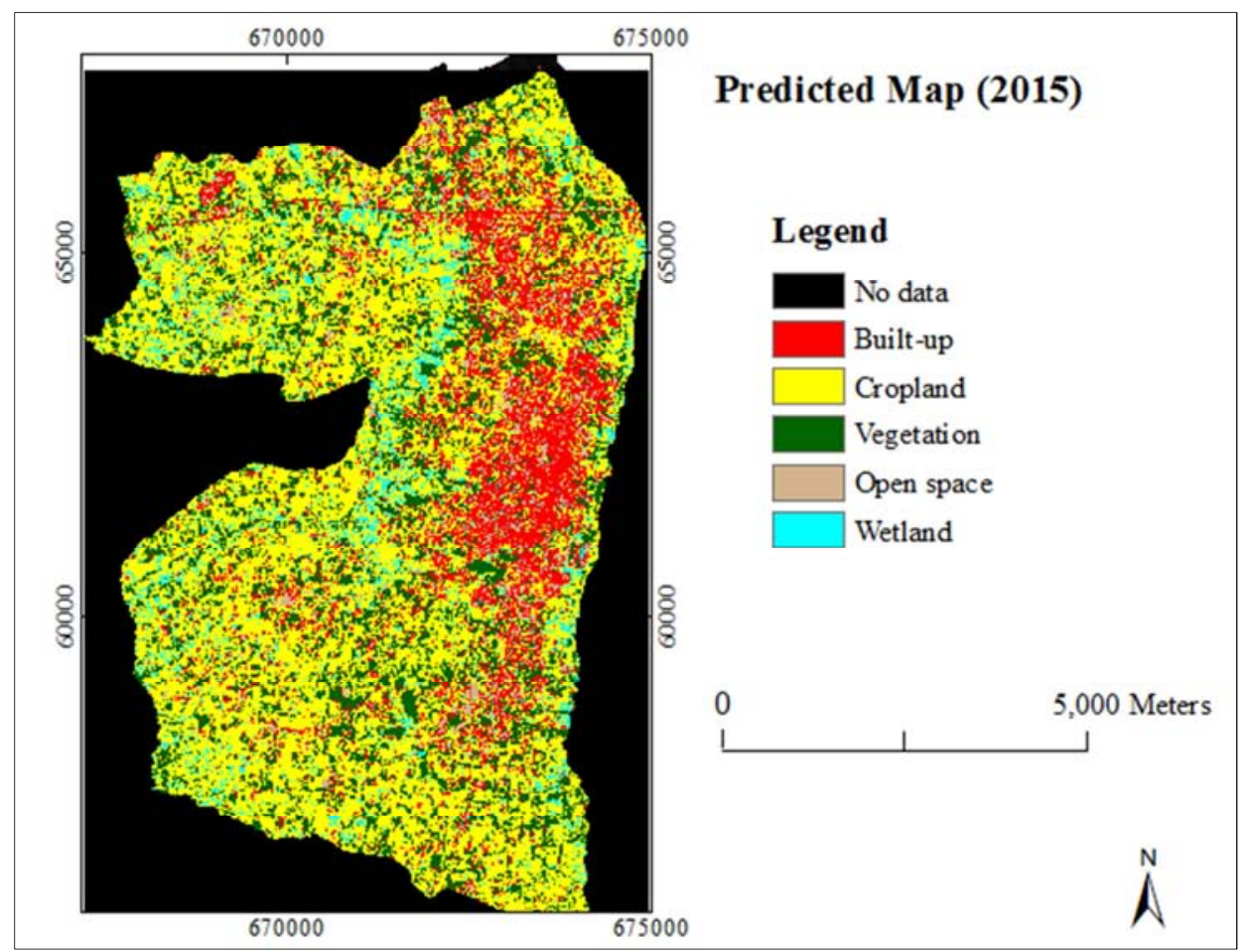

Figure 8. Predicted Map (2015).

\subsection{Per Category Kappa Statistics}

The validation was performed using the VALIDATE module of the IDRISI software. The approach involves statistical analysis that indicates the level of agreement between the simulated and classified land-cover map with regard to the quantity of cells in each class as well as the level of agreement between the two maps with regard to the location of the cell in each class $[5,7,16]$. 


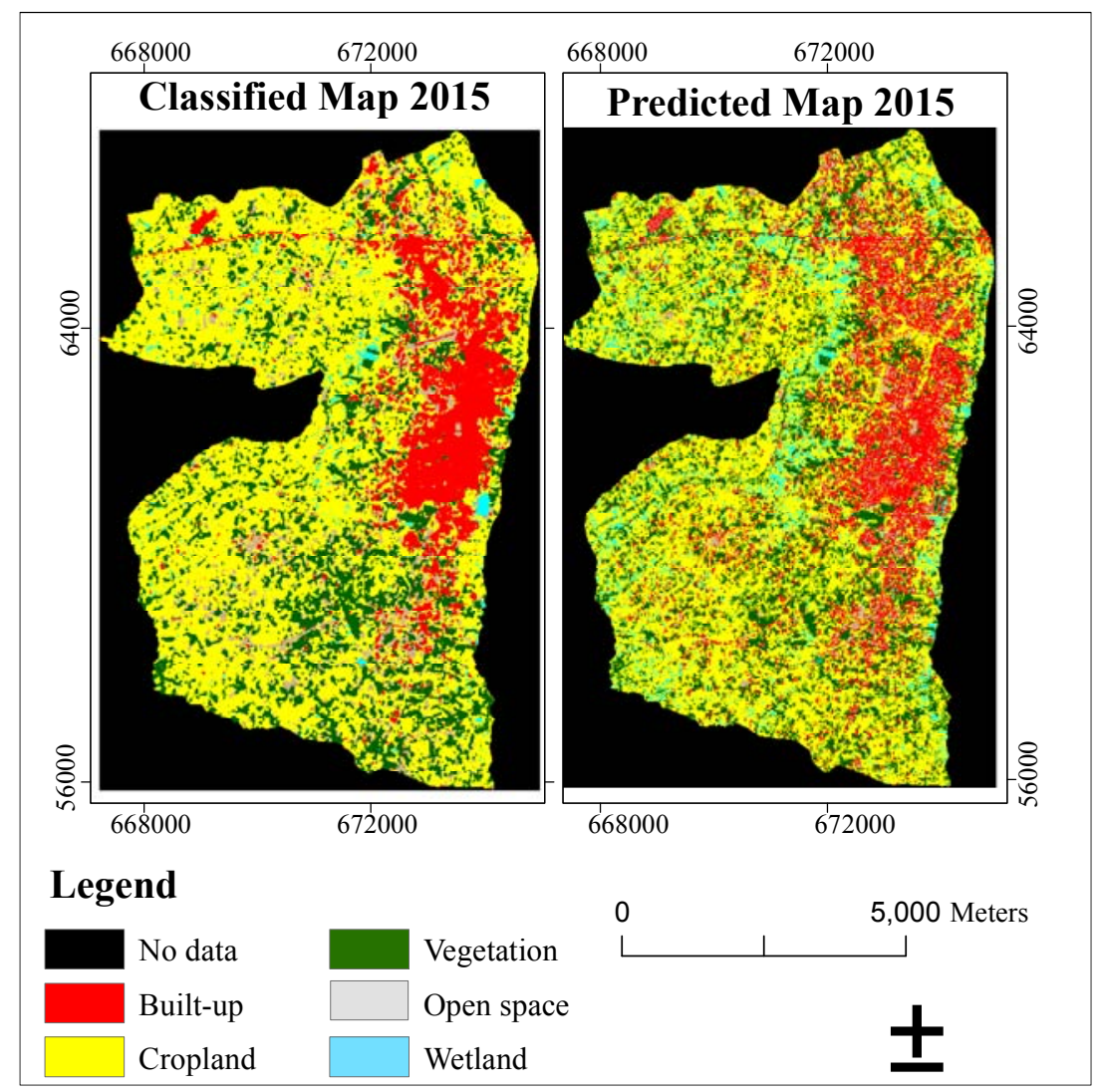

Figure 9. Classified Map (2015) Verses Predicted Map (2015).

Kno gives the overall accuracy of similarity between two maps. It is defined according to Equation (1) where $P(A)$ is the proportion of cases in agreement (i.e., correctly allocated) and $P(E)$ is the proportion of agreement that is expected by chance [12]:

$$
\mathrm{K}=\frac{P(A)-P(E)}{1-P(E)}
$$

Klocation is a measure of the similarity of the spatial location of categories of the two compared maps [12]. $P(\max )$ gives the maximal similarity that can be found based upon the total number of cells allocated to each category. Klocation is calculated according to Equation (2):

$$
\mathrm{K}=\frac{P(A)-P(E)}{P(\operatorname{Max})-P(E)}
$$

The kappa coefficients of per category show high values (Table 4). This proves that agreement between the two maps is substantial. Only wetland type is showing moderate value.

Using the classified images of 2000 and 2015 in a period of 15 years, the land use/land cover of 2030 was projected and analyzed.

Table 4. Per Category Kappa (K) Statistics

\begin{tabular}{llllll}
\hline & Built-up & Cropland & Vegetation & Open Space & Wetland \\
\hline Kno & 0.7944 & 0.9582 & 0.6621 & 0.6797 & 0.5548 \\
Klocation & 0.8448 & 0.9456 & 0.8613 & 0.8954 & 0.9235 \\
\hline
\end{tabular}

\subsection{CA-Markov Projected Land Cover Map of Bungoma Town (2030)}

At the end, Markov transition probability matrix, Markov transition area matrix (Table 5, Table 6), all the suitability images, the CA contiguity filter and the base map (classified map of 2015) were used to project the final land cover map of 2030 (Figure 11).

Table 5. Markov Probability of Changing among Land Cover Types (2000-2015).

\begin{tabular}{llllll}
\hline & Built-up & Cropland & Vegetation & Open Space & Wetland \\
\hline Built-up & 0.8315 & 0 & 0.1685 & 0 & 0 \\
Cropland & 0.0791 & 0.4345 & 0.4275 & 0.0298 & 0.029 \\
Vegetation & 0.0171 & 0.4756 & 0.4289 & 0.0146 & 0.0638 \\
Open Space & 0.1358 & 0.3113 & 0.3597 & 0.1902 & 0.0029 \\
Wetland & 0.0012 & 0.4062 & 0.286 & 0.0042 & 0.3024 \\
\hline
\end{tabular}


Table 6. Cells Expected to Transition to Different Classes (2000-2015).

\begin{tabular}{llllll}
\hline & Built-up & Cropland & Vegetation & Open Space & Wetland \\
\hline Built-up & 1696 & 0 & 344 & 0 & 0 \\
Cropland & 2150 & 11807 & 11617 & 810 & 789 \\
Vegetation & 480 & 13313 & 12006 & 410 & 1786 \\
Open Space & 167 & 382 & 441 & 233 & 4 \\
Wetland & 7 & 2185 & 1539 & 23 & 1627 \\
\hline
\end{tabular}

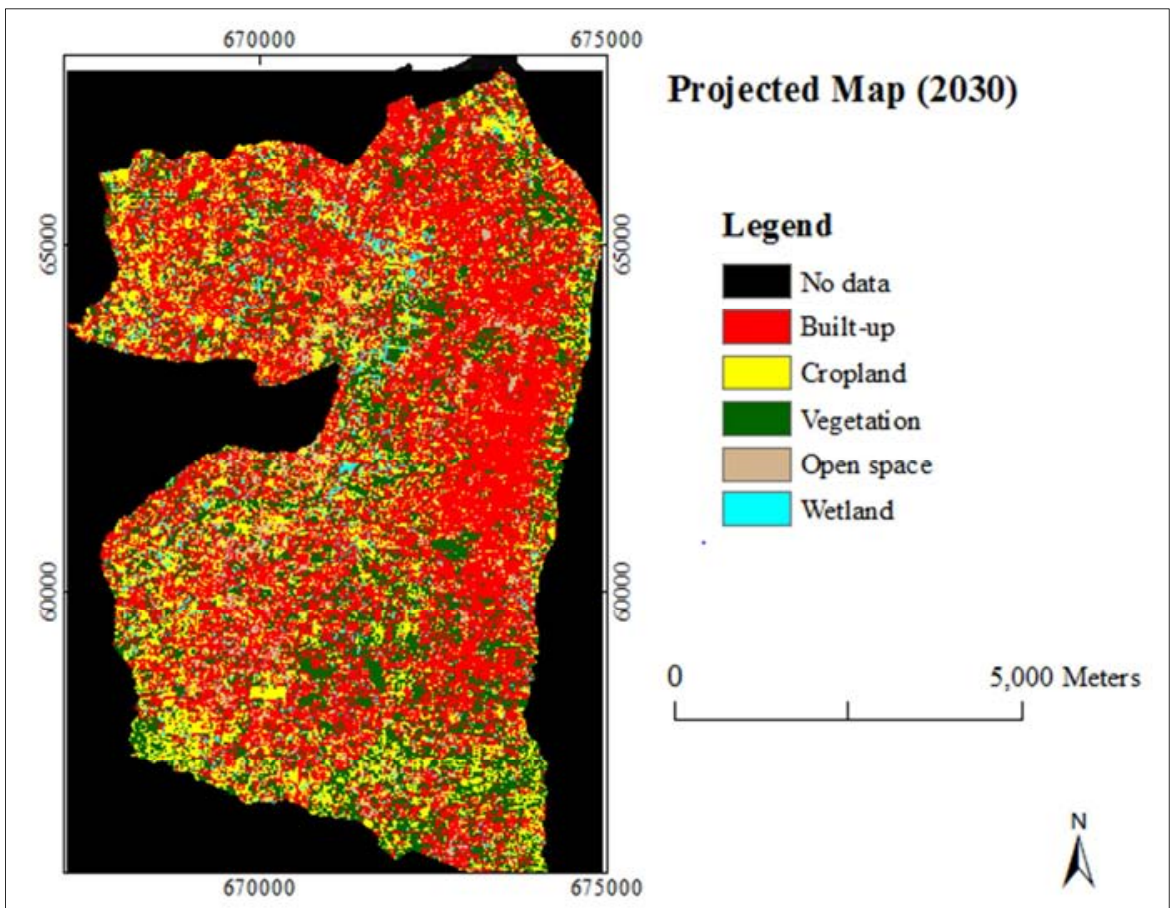

Figure 11. CA-Markov Projected Land Cover Map of Bungoma town (2030).Analysis of the Projected Map of 2030 shows that the area under study will be occupied by land cover types as follows: $52 \%$ built-up area, 19\% cropland, $20 \%$ vegetation, $5 \%$ open space and 3\% wetland (Figure 11 ). These changes could be attributed to increased population and faster economic development in the town.

\section{Conclusions}

Land use and land cover changes have wide range of consequences at all spatial and temporal scales. Identifying the complex interaction between changes and its drivers over space and time is important to predict future developments, set decision making mechanisms and construct alternative scenarios. In the period 1985 to 2015, Cropland area increased in huge percentage from $21.56 \%$ to $34.06 \%$ ) followed by builtup $0.41 \%$ to $13.76 \%$. It is also noted that vegetation and wetland decreased in good rate from $63.10 \%$ to $42.58 \%$ and from $12.89 \%$ to $11.20 \%$ respectively. Suitability map reveals the three different suitability categories that only approximately $4 \%$ of the study area is suitable for urban development. Areas that is moderately suitable for urban development is $71 \%$ and unsuitable areas consist approximately $25 \%$. The predicted map of 2030 reveals that the area under study will be occupied by land cover types as follows: $52 \%$ built-up area, $19 \%$ cropland, $20 \%$ vegetation, $5 \%$ open space and 3\% wetland (See Figure 11). These changes could be related to increment of population and faster economic development in Bungoma town. From this study it is important to note that CA provides important spatiotemporal information of land use and land cover changes especially on urban areas. It also provides the possibility to understand the influence of urban dynamics supported by a set of drivers. Model results have shown remarkable changes in built up areas between the study periods.

\section{Acknowledgements}

The successful completion of this research would not have been possible without the support and contributions of various individuals. Firstly, I sincerely thank my supervisor Dr. Andrew Imwati for his tireless support and guidance throughout the study. He was always readily available for any assistance and his advice and constructive comments were great asset throughout my research period. I also wish to acknowledge the support of Dr. J. Mwangi of Civil Department and members of staff, Department of Geomatic Engineering and Geospatial Information Systems, Jkuat, for their self-less effort to ensure that I achieve my research objectives.

\section{References}

[1] Bayes Ahmed and Raquib Ahmed. Modeling urban land cover growth dynamics using multi-temporal satellite images: a case study of dhaka, bangladesh. ISPRS International Journal of GeoInformation, 1 (1): 3-31, 2012. 
[2] Bungoma Assembly. Cidp report, Jul 2017. URL http://www. bungomaassembly.go.ke/download/advertisements/.

[3] DEPARTMENT OF PHYSICAL PLANNING. NATIONAL SPATIAL PLAN CONCEPT PAPER. Technical Report November, 2010. URL https: //landportal. org/sites/default/files/concept paper nsp.pdf.

[4] Dezhkam, S., B. J. Amiri, A. A. Darvishsefat, \& Y. Sakieh. 2017. "Performance Evaluation of Land Change Simulation Models Using Landscape Metrics." Geocarto International 32 (6): 655677.

[5] Eastman, J., R. (2012). IDRISI Selva: Guide to GIS and Image Processing. Worcester, MA: Clark Labratories, Clark University.

[6] KNBS. Economic survey 2009, Dec 2009. URL https://www.knbs.or.ke/ download/economic- survey-2009-3/.

[7] Ibrahim, S., Hashim, M., \& Reba, M. N. (2018). Geospatial modelling of urban growth for sustainable development in the Niger Delta Region, Nigeria. International Journal of Remote Sensing, $00(00), \quad 1-29 . \quad$ https: //doi.org/10.1080/01431161.2018.1539271.

[8] Liu, Y. (2008). Modelling Urban Development with Geographical Information Systems and Cellular Automata (1 ed). Florida: CRC Press.

[9] Marina A. Modeling the urban ecosystem: a conceptual framework. Environment and Planning B: Planning and Design, 26 (4): 605-629, 1999.

[10] Mundia C. N. \& Yuji M. Modeling spatial processes of urban growth in african cities: A case study of nairobi city. Urban Geography, 31 (2): 259-272, 2010.
[11] Mubea, K., Goetzke, R. \& Menz, G. (2013) Simulating Urban Growth in Nakuru (Kenya) Using Java-Based Modelling Platform XULU. UKSim-AMSS 7th European Modelling Symposium, Manchester, 20-22 November 2013, 103-108. http: //dx.doi.org/10.1109/EMS.2013.18.

[12] Mubea, K., \& Menz, G (2014), Spatial Effects of Varying Model Coefficients in Urban Growth Modeling in Nairobi, Kenya, (December), 636-652.

[13] Mundia C. N. \& Yuji M. Modeling spatial processes of urban growth in african cities: A case study of nairobi city. Urban Geography, 31 (2): 259-272, 2010.

[14] Musa, M., K., \& Odera, P. (2015). Land use land cover changes and their effects on agricultural land: A case study of kiambu county -kenya. 3:74-86, 052015.

[15] Musa, S. I., M. Hashim, \& M. N. M. Reba. (2017) “A Review of Geospatial-Based Urban GrowthModels and Modelling Initiatives." Geocarto International 32 (8): 813833. doi: 10.1080/10106049.2016.1213891.

[16] Pontius, R., G., \& M., Millones. (2011). "Death to Kappa: Birth of Quantity Disagreement And Allocation Disagreement for Accuracy Assessment." International Journal of Remote Sensing $\quad 32 \quad$ (15): doi:10.1080/01431161.2011.552923.

[17] Townroe, S., \& A. Callaghan. 2014. "British Container Breeding Mosquitoes: The Impact of Urbanisation and Climate Change on Community Composition and Phenology." PLOS ONE 9 (4): 1-7. doi: 10.1371/journal.pone.0095325.

[18] Wei, Y. D., \& X., Ye. (2014). "Urbanization, Urban Land Expansion and Environmental Change in China." Stochastic Environmental Research and Risk Assessment 28 (4): $757-$ 765. doi: $10.1007 / \mathrm{s} 00477-013-0840-9$. 